\title{
The beauty of his holiness
}

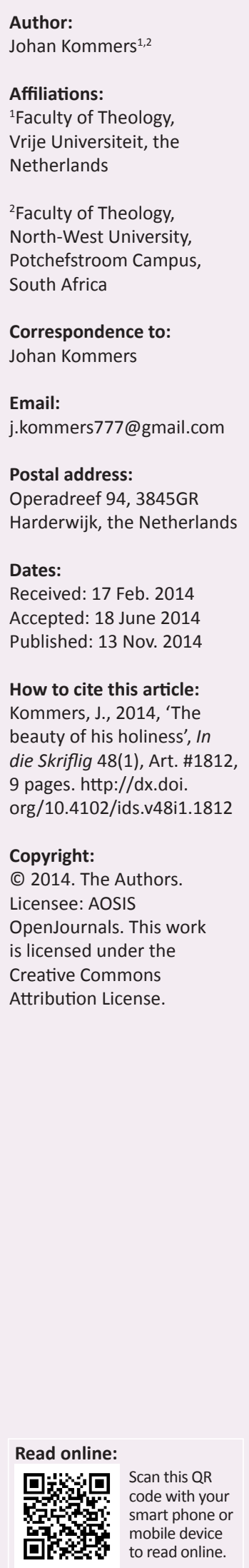

The founder of the Keswick Convention (KC) once was asked to put in a sentence that has brought such a joy into his life and made the name of Keswick fragrant over the whole world. The answer was in the words of the Psalm 16:8, 'I have set the Lord always before me'. Keswick theology, emphasising sanctification, arose within the concept of the holiness tradition in America with the higher Christian life movement in England during the second part of the 19th century. The merging of several theological traditions formed a way of expressing oneself and a way of life, which was determined as typical 'Keswickian'. It also found expression in other theological (conservative) movements, in new founded institutions and gave a boost to missionary enterprise. The language and the teaching of Keswick until today clarify the pattern of evangelical piety of the 20th century.

De ogen gericht naar God. De stichter van de Keswick Convention (KC) werd gevraagd, om in één zin te zeggen wat hem zo"n vreugde gebracht had in zijn leven, en wat de naam Keswick zo'n welwillende naam over de hele wereld heeft gegeven, zijn antwoord was met de woorden van Psalm 16,8,- Ik stel mij de Heere voortdurend voor ogen. De theologie van Keswick, waarin de heiliging benadrukt wordt, kwam op binnen het concept van de heiligings traditie in Amerika met de hoger christelijke leven beweging in Engeland gedurende de tweede helft van de negentiende eeuw. Het samengaan van verschillende theologische tradities gaf een manier van expressie en van leven dat gezien werd als typisch voor Keswick en vond uitdrukking in andere theologische (conservatieve) bewegingen, in nieuw gevormde instituties en het gaf een stoot aan het zendingswerk. Vandaag nog verduidelijkt de taal en het onderwijs van Keswick het patroon van Evangelische vroomheid in de twintigste eeuw.

\section{Introduction Keswick: Meeting place with God}

Driving on the main A591 south-north route between Grasmere and Keswick, the traveller is always tempted to stop and view the stunning scenery. Nearing the busy capital of northern English Lakeland, it is clear that times have moved on since the first Keswick Convention (KC) held in 1875 . Nearly 140 years later the encompassing hills of Keswick remain as enchanting as ever and have retained its beauty. The author, on his way to the $\mathrm{KC}$ premises, agrees what a visitor once exclaimed (The Keswick Week [TKW] 1955: first page):

\footnotetext{
'Beauty is here, aye, beauty rare,

But something fairer seek we here,

"Beauty of holiness": to see

Thy face in glorious majesty'.
}

For most people this town in the Lake District is dedicated to country life and many tourists visit each year. However, once a year, in July, many come not primarily for a holiday, but first and foremost to meet with God. In July 1875 a few 100 evangelical Christians met here for, what has become since then, the KC. For nearly a 100 years the KC was held for only one week each year. As the numbers attending increased in the last decades of the 20th century, it was decided in 1969, to extend the time to two weeks, and in 2013 to three weeks. During the day strong sounds of praise ring out, together with worship notes of intercession. People from all over the world have their Bibles open, and in the gatherings the responsibilities and privileges of the full-orbed Christian life is presented. The convention week is closed with a united communion service. There is an attracting power in the Gospel and appeals to leave sin, and for complete surrender, culminating in full consecration to God are often made during the addresses to the thousands who hear:

No statistics are ever given of the result of all these appeals. No decision cards are issued, and it is only in the quickened lives of many, in city and country, at home and abroad, that the sweet savour of 
Christ discovered at Keswick, is spread throughout the world. (TKW 1930:163)

In our millennium, it was John Stott (2008), who, 'in our non-Christian society, even in a pluralistic, secular culture' confronted the thousands of Keswick visitors in 2000 with the same emphasis on the message than his predecessors 100 years ago. 'Holiness, not as the grounds of salvation, but as the evidence of our salvation' (Stott 2008:501, 503). Keswick is not a religious picnic, but a time of earnest waiting on God and learning from Scripture expositions.

\section{What was in the air?}

The 19th century was an age of action. The dawn of the age had seen Wilberforce's action and triumph for the abolition of the slave trade. Quakers like Elizabeth Fry, transformed women's prisons from bestial hells into reasonable establishments with laundries, schools for children and religious instruction for all. Children, condemned to working all day in factories or dark mines, were rescued from this work by Lord Shaftesbury. The source of all that love and energy was kept alive by groups of evangelical Christians who heard men and women speak on consecration to Christ and the fullness of the Holy Spirit. During the second half of the 19th century, the watchwords of surrender and holiness were everywhere in the United Kingdom. Bishop Handley Moule (1841-1920), who strongly influenced the Keswick teaching, conveyed his thoughts during Moody and Sankey's evangelistic visit in 1882 about that time (Taylor 1930):

There was an almost passionate desire for entire deliverance from the power of sin. That sacred impulse sometimes took dangerous directions and many an anxious hour some of us had seeking to guide men to achieve a balanced life to holy soberness; but the whole result, I say unhesitatingly, was nobly good, and many a day since then I have almost prayed for the aberrations back again for the sake of the wonderful life (p. 82).

The origins of this new interest for proclaiming holiness was in the network of keen evangelicals around William Pennefather. ${ }^{1}$ The issue of holiness, rooted in earlier Wesleyan teaching, was a key formative factor to understand the spirituality of the evangelical circles. Wesley emphasised in his teaching sanctification, which was popularised by outstanding personalities who stressed holiness amongst Christians to enable them to work together in effective evangelism. The interest in evangelism and personal consecration grew since 1864 when many articles on the subject of holiness were published, especially by the pen of Robert Pearsall Smith, an American of Quaker background, who had embraced since his conversion entire sanctification. From 1856 in Christ Church, Barnet, and from 1864 in St. Jude's at Mildmay Park in North London, Pennefather held an annual conference that drew together Christian workers with a strong interest in evangelism and personal consecration. These kind of conferences emerged all over England, attended by people from all walks of life and later, it crystallised into the annual KC. The 1859 Revival (Gibson 1989) ${ }^{2}$ also had a broad impact in the British evangelical world. 'Keswick was an indirect outcome of the 1859 Revival' (Stevenson 1959:14). Throughout the mid-Victorian era towards the end of the 19th century the evangelical movement was the strongest religious force in British life (cf. Chadwick 1966:5). Its leaders and also the future Keswick leaders spoke out against the apathy and half-heartedness of all too many Christians. They stressed the union of the believer with Christ and the presence of the Holy Spirit.

\section{Holiness teaching}

Keswick leaders always emphasised, contra the opinion of many respected church leaders of the time that what they taught, was not new. For them it was stating afresh in present day language, in The Gospel-Mystery of Sanctification written in 1692 by the Puritan divine Reverend Walter Marshall. Whilst stated largely in Calvinistic terminology, the emphasis upon the inward work of grace is wholesome. Theologically it forms more or less a transition to the teachings of the Wesley's in the 18th century and they, in turn, influenced the 19th century evangelical piety. The history of this piety leads us back to roots in North America and the experience of 'rest' amongst the Quakers who associated this with holiness (Bebbington 1989:156). Holiness became a major aspect of the spirituality of the time for many churchgoers who also emphasised pre-millennial advent teaching, sanctification and the faith mission principle. Whitfield Guinness, a member of the Cambridge Inter-collegiate Christian Union (CICCU), noticed that, during his student days in the 1880 's, Cambridge was the centre of a spiritual movement, which was reaching the ends of the earth. The Moody and Sankey campaigns brought thousands to faith. They spoke of 'full consecration' that empowered many Christians for evangelism.

The American couple, Robert (1827-1898) and Hanna Pearsall Smith (1832-1911), travelled in 1873 to Britain, participating in several Higher Life conferences. Hanna especially made a particular impact with her teaching, summarised in the book The Christian's Secret of a Happy Life (Smith \& Smith 1873). From Quaker family she claimed, 'that the Lord is able to save you fully, now, in this life, from the power and the dominion of sin, and to deliver you altogether out of the hands of your enemies' (Price \& Randall 2000:14, 15). This was no intellectual concept, but a 'dynamic experience', which it was rather unwisely called by one of its early American proponents, William Boardman, who published his influential book The Higher Christian Life $e^{3}$ (1859). Hanna herself preferred the expression 'the life hid with Christ in God'.

During 1873, the Pearsall Smith couple held small meetings in London where they spoke about the duty and privilege of present victory over besetting sin. According to Pierson, 2.This book describes the 1859 Uilster Revival.

3.This book has been the most influential in arousing interest in sanctification and the Spirit-filled life (Barabas 1952:16). 
God's angel stirred the pool, and there were reports of great blessings. The little meetings became crowded and led to larger gatherings in other and more commodious places (Pierson 1903:17). In January 1874, meetings for the promotion of spiritual life were held in St Jude's Church, Mildmay (London), followed by other and similar meetings in many cities, and even on the continent of Europe. Their report stated that many who attended, whilst:

thoroughly grounded in the assurance of salvation [...] have been led to inquire whether there was not, presented to them in Scripture, the standard of an available life of practical victory over all known sin, and of maintained communion with their Lord, which they had not yet grasped. (Rowlandson 1997:4)

It was found that where these meetings were held, they were accompanied by:

a deeper sense of sin and need, an expectation of fuller blessing, a nearer approach to God in prayer, and, what was perhaps most remarkable, a new and surprising transformation of temper - a renewal of the spirit of the mind, the last stronghold of sin to be taken for Christ. (Pierson 1903:20)

The 'Union Meeting for the Promotion of Scriptural Holiness', held at Oxford and Brighton in 1874 and 1875 respectively, are regarded as the birthplace of the KC. The great convention at Brighton attracted 8000 people to the meetings that lasted for 10 days. The vicar of St. John's Church in Keswick, Canon Harford-Battersby, was one of the attendees. There he received rich blessings and resolved that a convention should be held in Keswick for Christians, living in Cumbria, to get the opportunity to attend. In a letter ${ }^{4}$ to Robert Wilson he wrote:

I am inviting Mr. R.P.S. [the initials are in the letter $]^{5}$ to Keswick for the middle of the month of June. [...] I have projected a series of meetings in Cumberland and think that the time named would be the best. (Cummings 1875)

Another letter (Cummings 1875) 14 days later says, 'We must remember that the object of the meetings would be to promote the full sanctification of believers.' On 28 June 1875 it was announced that Mr Pearsall Smith would not come due to illness (cf. Pollock 1964: ch., 4).

The first meeting under the title 'A Convention', began on 28 July 281875 and was held in a large tent, hired for this purpose. As many as 600 people attended the first Keswick meeting. Keswick became more and more important in the wider desire for holiness that was a marked feature of the second half of the 19th century (Gordon 1991:203). "Holiness unto the Lord" is unquestionably the key-thought of all these gatherings' (Webb-Peploe 1910:4-5; Murray 2013:1). Holiness is not to live a life far from the daily reality. 'Does it find exhibition in your life that the Christ of God, and finally as Lord, is really a power in your daily existence?' (WebbPeploe 1910:5).

4.Letter dated 09 March 1875.

5.Robert Pearsall Smith.

6.Letter dated 22 March 1875.

\section{Key thoughts of the Keswick Convention}

The KC is connected with leading names: Anglicans like H.W. Webb-Peploe, E. Hopkins, E.W. Moore, W. Haslam, M.H. Aitkin, Bishop Moule; Baptists as F.B. Meyer and the Quaker Robert Wilson (co-founder of the $\mathrm{KC}$ ), together with the missionaries Hudson Taylor (China), Lilias Trotter (Algeria) and Amy Carmichael (India). From outside England: Theodore Monod (France), Andrew Murray (South Africa) and A.T. Pierson (America). All these and other Keswick leaders were men and women of wide undenominational sympathies. For instance Robert Wilson, chairman of the KC from 1891-1900 and a Quaker himself, also taught in a Baptist Sunday School and regularly visited the Anglican Church. He was also the selector of the Keswick motto, 'All One In Christ Jesus', and was responsible for the three flags, 'Love - Joy - Peace' flying over the tent. Handley Moule, Prebendary Webb-Peploe and A.T. Pierson were the three who represented Keswick's teaching at that time. Moule was the living epitome of the $\mathrm{KC}$ 's message. In short his message was: 'Complete surrender of the soul to God and complete trust in Him for His mighty victory within' (Taylor 1930:84). Due to these three biblical-grounded people, Keswick has been preserved from the extravagances, the eccentricities and the catastrophes which have so often developed in connection with holiness teaching. Evangelical holiness always follows submission to the Bible as the Word of God. The meetings in Keswick were not conferences, not a place for debate, but conventions for strengthening, encouraging and assisting each other in the Christian faith.

\section{The invitation to the first convention in 1875 was:}

We implore all who are interested in the welfare of the Church of Christ, and in the advancement of practical holiness, to unite with us in earnest prayer for the guidance of the Holy Spirit in the arrangements of these meetings, and for His blessing on the teaching and testimony of God's servants. (Sloan 1935:23)

These two factors, the welfare of Christ's Church and the advancement of practical holiness; and their interdependence, are as important today as when these same words were quoted again in the 1908 Convention. To them were added the words from the Bampton lectures that year: 'The startling contrast between the lives of Christians and the rules which they profess to accept, is the great religious difficulty of the present day' (TKW 1962:5).

Strongly influenced by Methodism and the Plymouth Brethren, British evangelicals - many of them Anglican Low Church Christians - tended to the teaching of strict literalistic interpretation of Scripture, a conservative pietistic lifestyle and a biblical faith. In the early years there were many testimonies of a practical deliverance from the power of besetting sin and a constant and lasting blessing, founded in the keeping power of Christ. Many convention visitors referred to it as a 'second blessing' (Harford 1907:79). If 'purity' was the keynote in the early stage of the $\mathrm{KC}$, we can 
say 'power' was the second important. Now the doctrine of the Holy Spirit's work and his empowering and fitting for the service came more into focus. So was it said at the 1884 Convention when J.G. Govan explained that Keswick revived the old-fashioned testimony of the 18th century revival to heart purification by faith as a distinct experience subsequent to conversion.

In the later years of the $\mathrm{KC}$, more and more prominence has been given to the missionary call to the Church of Christ. Salvation in its fullness requires service as the outcome. They began to see, and therefore to tell, what the real meaning of true cleansing and consecration, of real filling and fitting would be in the living Church. Such a church can look to no smaller end, be content with no narrower limits, and rest in no shorter attainment than 'The evangelization of the world in this generation'.?

Faith is prominent in Keswick teaching. From this came the emphasis on peace, rest and victory over sin when God defeats the enemies of the soul. The adherents of Keswick upheld holiness by faith as their central conviction. Like the Methodist tradition from which it emerged, Keswick maintained that there should be a point of full consecration as well as subsequent steady progress in Christian life. This idea was summarised by Moule in 1900, who defined Keswick teaching as 'a crisis with a view to a process'. Where there is full surrender, men will look to God. Moule, an excellent exegete, emphasised the spiritual significance of the aorist tense in the programme of holiness. Bible promises appear as divine possibilities 'Alps to be attempted, not stars to be admired' (Harford 1907:179).

Dealing on the costliness of our salvation it was stated: 'This Convention, its message, all that it may do, and all that it has done, depends upon the preaching of the Cross' (TKW 1959:11). These poignant words cover everything that Keswick stands for. It is not so much the discovery of a new truth as of new life. The promises and commandments of God were unchanged, but there was a new grasp on the promises and new strength to obey the commands. People saw and knew that God means what he says; that his word of command is an assurance of ability to perform. In its essence, the teaching of holiness by faith is not a substitute for justification by faith. The Christian is expected to be a 'vessel' sanctified and made for the Master's use.

With Keswick's message a new spiritual blessing entered the churches. The presence of God, the saving grace of Christ and the work of the Holy Spirit became realities in people's lives and in churches. Since 1881 the Keswick traditional

7.A.J. Broomhall, the historian of the China Inland Mission (CIM), remarked that 1875 was 'the point at which the tide of all missions to China turned [...] The dawn of 1878 brought in the age of Protestant missionary expansion'. Broomhall's publication The Evangelization of the World influenced dr John R. Mott. Some years after the publication the title of this book became part of the motto of the Student Volunteer This watchword was not a prophecy that the world would be evangelised in the This watchword was not a prophecy that the world would be evangelised in the
present generation, but an affirmation that it might be and should be so evangelised in the sense that every generation of Christians is responsible for evangelising the world of that present generation, and not that by human activities and efforts this world of that present generation, and not that by human activities and efforts this
could be realised. The conversion of men is a work of Grace and is in God's hands; the power to convert men does not lie in the hands of men.
Bible readings have been the central part of the convention week. In the subsequent 30 years Reverends Brooke and Webb-Peploe almost exclusively undertook the daily Bible readings. From 1914 there was a rather wider choice of speakers delivering the Bible readings. Going through the messages delivered at Keswick it is a surprise to see that the section of Scripture, generally regarded as central to the Keswick message, namely Romans 5-8, was not the subject of any series before 1937. It may be noted that, in general, this evangelical piety was biblical and puritan, and, in line with this, Keswick focused more on a gospel of indwelling than on one of objective atonement (Chadwick 1971:471). Keswick insists upon the reliability of God's promises of conquest and the possibilities of cleansing in heart and thought, of a retentive power by which Christ transforms the will and transfigures life. Faith lays hold of the risen Saviour and triumphs in him (cf. 1 Cor 6:4). Keswick could deal with the rest people have in their hearts. Its 'quietism' is not to work less, but to trust more; believers lose their burdens and apply the biblical principle to forbid worry (Ps 37; Phlp 4). Believers cast their anxiety upon Christ once and for all (1 Pt 5:7; note the aorist form in Greek). Christ does not remove the stress of work, but he does relieve the strain of worry. The Keswick message promises power for service: The Holy Spirit gives power to the weakest. He is the agent; we are the tools, with added joy we are conscious and willing instruments. His power is humbly claimed, his voice obeyed and his presence enjoyed.

\section{The promotion of full salvation}

There is nothing formal or rigid about the sequence of Keswick teaching. It is recognised that true abhorrence of sin, worked out by a confession and renunciation of it, are the steps toward 'fullness of the blessing of the Gospel'. Keswick disagreed with the teachings that certain gifts of the Spirit like speaking in tongues are strongly manifested. For Keswick, faith is the evidence of the filling of the Spirit, and not the outer extravagant manifestations. Faith involves full surrender and implicit trust in God. In order to walk by faith, a believer is looking to Jesus and not to physical evidence or manifestations. This is the emphasis on holiness in the Wesleyan sense, that is, the possibility of the Christian living a life of faith, free from the stain of sin and focussed on missions. From the very beginning Keswick opposed the 'perfection in man' idea, which was seen as a 'very dangerous heresy'. Webb-Peploe (1910) explained every time:

Of full and Divine perfection in man we know nothing here. I trust there is not one who will ever appear on the Keswick platform who will profess to say that he is perfect. [...] and the thoughtful person will have to acknowledge that he does come short - 'We have sinned, and do come short of the glory of God'. (p. 6)

Sin remains in us to the end, but through Christ and by his Holy Spirit's power, he will keep the true believer moment by moment from falling into known and unknown sins, even though every thought, word and deed of the believer, until 
the last moment on earth, is tainted by the fact of indwelling sin or corruption. The blood of Christ is continually needed to cleanse us from guilt and keep us acceptable in the sight of the holy God. In the early years of Keswick there was opposition and prejudice to be overcome before the Gospel of a keeping Saviour could be welcomed. In particular, those who proclaimed 'justification by faith' thought that human effort was the chief element in sanctification. Many criticisms came from those who were disappointed by the behaviour of Pearsall Smith, who himself embraced the thought of 'sinless perfection', although even he, as was said, fell into great sin. Often many of these Christians attending the conventions were dispensationalists, which further strengthened their missionary resolve along the lines of Matthew 24:14. Those attending the convention come to Keswick with the express intention to know something of the wholeness which they believe, is in Jesus Christ. Cowper's prayers 'Oh, for a closer walk with God, A calm and heavenly frame' and 'God moves in a mysterious way', are often remembered by the thousands who attend. Their confidence in the Scriptures as the Word of God from Genesis to Revelation was simple and total. To be ready to lay down one's life in sacrificial service, is having the marks of a Christian whose life is beginning to count and be of value in the world. On the opening night of the 1911 Convention, Reverend Hopkins, whose name is always linked with the KC summarises what the people were looking for:

The first thing is to see whether we are right with God. [...] We must submit, by trusting to Christ. Then we must commit, by trusting to Christ what you yourself have failed to manage. (TKW 1962:6)

This was quoted on the 1962 Convention and the speaker then goes on:

As in earlier times, so today, the emphasis on personal holiness needs to be shown, not as an exotic bloom to be grown in the greenhouses of sheltered Christians, but as the hardy perennial which should be the common flower in the garden of every work-a-day Christian where ever he may find himself. (TKW 1962:6)

Hopkins lived close to God. Once he prayed: 'Give us a divine conscience about keeping our time with Thee untouched' (MacBeath 1949:67). Keswick always insists that Christ is the focus of all Christian living.

\section{Introspective and Christian service}

The classic Keswick Bible teachings were not gatherings meant for the discussion of Christian truths, but it was intended to be declarations of one message only. The first series of 'Bible Readings' were delivered in 1881 and since 1900 the Bible readings were connected series. These readings have come to be regarded as one of the most potent spiritual forces in church history since 1875 . The Keswick Week gives a sense of God's working, a 'coming to grips' with spiritual issues to those who attend. There is a unity in Jesus Christ, the one and only, and irreplaceable object of faith and baptism. Stott said to Keswick that 'this essential, indestructible unity, transcending racial, social, denominational differences, is gloriously demonstrated' (TKW 1962:36). ${ }^{8}$ Keswick honours the Word of God - in fact this is the chief secret of its influence. It is recorded several times that at the end of a speech, the thousands who heard the message were silent for a time. The awe of the Word was upon them and for many hearers the message had momentous consequences, because life's purpose was settled.

Is the ministry of Keswick far too introspective? There has to be a time and a place for careful, deliberate, unhurried and completely honest self-examination. Repentance is the bridge over which the mercy of God travels to the sinner. There is always the appeal to look at the blessed Lord, exalted at the right hand of the most high. That will arise and create $a$ consciousness of $\sin$ in our hearts. 'True spiritual experience has to begin with God, convicting us of sin' (Murray 2013:5). Many people feel they have to come to Keswick, because it is where the Lord wants to speak to them so that they can recognise him as their Creator, their Redeemer, and their indwelling Lord.

In the convention priority is given to the introspective teaching of $\sin$ in the life of a Christian, but it does not end there. In the teaching they look upward and outward to the reality of the fullness, the promise, the possession and the purpose of God, since it is his purpose, 'that ye might be filled with all the fullness of God'. Keswick goers say: 'The Lord Jesus received is holiness begun; the Lord Jesus cherished is holiness advancing; the Lord Jesus counted upon as never absent would be holiness complete' (TKW 1962:103). It has been said that people, attending the convention, do this to fuel their 'feel good' thoughts. In 1926 Reverend Aldis said:

We have not come to Keswick merely to attend the Convention meetings and to feel good, but we have got to deal with secret sins and let the searchlight of the living God go right through us. (MacBeath 1949:68)

\section{One listener's reaction to Aldis's addresses was as follows:}

His addresses had none of the polish of the poet or literary craftsman. They were drastic and urgent and searching [...] The natural sluggishness of mankind and the human proneness to inertia found in him a disturbing speaker. (MacBeath 1949:68)

Keswick speakers were like soul surgeons, prescribing how to stand in the presence of God. When deep impressions were made on the people, they were aware of their sins against a holy God so that vows might be made in his presence. Convention-goers were summoned away from introspection or mere contemplation and were enlisted for service. Emphasis on holiness without service can lead to unhealthy introspection. The opposite is also dangerous the challenge to service without a deep foundation in a life 8.Stott also said that 'The Christian life is a Christ-centred life.' Paul saw his mission in Corinth as 'a testimony to Christ' (TKW 1962:36 and 37). 
of holiness can be superficial activism. By sanctification was meant what Paul says in 1 Corinthians 1:30 'Of Him are ye in Christ Jesus, who of God is made unto us ... sanctification.' Paul speaks of it as an impartation, never as an imitation. In Christ Jesus is the perfection of everything. In him the Christian does not have the start of holiness, but the actual holiness of Jesus Christ (cf. Col 1:27). God does not give us the power to imitate him; he gives us his very self. Keswick's 'quietism' has nothing to do with quiescence, but a growing and living trust to transfer the burden and to cast the anxiety upon Christ once and for all. Keswick's aim is that: sin must die in me. John Wesley's influence is still felt in the Keswick teaching today. God does away with sin, and a wave of piety occurs 'which takes the form of devotion and sentimental religious activity whilst the real message of the Gospel is lost by obliteration' (Chambers 2000:32). These words of Chambers warn us against an emphasis on a second definite work of grace in which the pious man is the focus. Important in sanctification is the emphasis on the regenerating power of God, and not on our individual consecration, fasting, prayers and our individual devotion to God. Jesus is both Saviour and Sanctifier.

Keswick made a major impact in South Africa. The addresses of Andrew Murray at the 1895 Convention had a tremendous impact on everyone who heard him. He became a leading exponent of its sanctification teaching. A convention at Wellington in the Cape was forerunner to many others such as Johannesburg, Cape Town, Port Elizabeth, Durban and Kroonstad. Murray's convention hymnbook sold more than 50000 copies (Douglas n.d:172-174).

\section{Higher or Victorious Life}

One of the main reasons for the existence of Keswick is to demonstrate that it is possible through the grace of God to live a Christ-like life. Keswick tells us of the identification of our life with Christ in his death and resurrection and that the heart's lust and appetites can be brought under subjection by living in close fellowship with him. To get a vision of Christ and his close relationship with his disciples would cause the distinction between the religious and the daily Christian living to vanish. Fellowship amongst Christians of different denominations occurred and the speakers, from different denominations, never stressed their own dogmatic issues. For instance, concerning holiness, it was never discussed at Keswick for a man to be sinless in the present life, as some were inclined to say. It was a confirmed point from the first convention. It was, in fact, stated in one of Keswick's notes. Theodore Monod had already said in Oxford, 'We ought not to sin, and we need not to sin, but as a matter of fact, we do sin' (Harford 1907:107). What Webb-Peploe told the meeting in 1876, 'You have no perfection in men, but you have a perfect Saviour' (Harford 1907:107), is biblical. Sanctification was seen as spiritual health, a continuous work of grace (cf. Phlp 3:13-14). In Keswick there was harmony about Christ and his atoning work, a longing to experience the resurrection life and to have as our life-motto 'That God May Be All In All'.?

\section{Pre-millennial view}

Pre-millennial thought became widespread in the first decades of the 19th century and many church leaders were attracted to the apocalypticism of the pre-millennial view. Respected KC speakers such as F.B. Meyer and G. Thomas were committed to the pre-millennial view. Keswick had a ready affinity for a declared pre-millennial approach to prophecy, which anticipated the hope in the future (cf. Bebbington 1989:83-88). The Lord's return is an issue that appears several times throughout the years in addresses delivered at the convention (cf. TKW 1947:238-243). One of the early speakers, Griffith Thomas, who frequently spoke at the convention, strongly advocated that the Lord's coming is pre-millennial. This view is also the inspiration of Christian service. Men like Moody, Spurgeon, Hudson Taylor, ${ }^{10}$ George Müller and Arthur Pierson were also exponents of pre-millennialism. Griffith Thomas explained his views very wordy at the 1914 Convention (Britain was then in the throes of war!):

Have you noticed the three appearings of Christ. (in Hebrews 9, 24,26 and 28)

[...] When every member of His Body has been won, and when that Body is completed, He is coming, not to the earth, but into the air for His people. Then He will be coming with His people. I am not concerned with details.

[...] But I ask you to notice the glory of this future when He will come with His saints, and then reign over the earth, ushering in what we believe to be the Millennium, that wonderful time of which the Old Testament is so full. (Stevenson 1963:227)

Those who believed in the imminence of the Second Advent and its decisive divine entry into history, were attracted by the idea that the power of God could already break into human lives.

During the first decades of the 20th century the emphasis on the pre-millennial approach diminishes. To the question asked in 1966: 'What is Keswick for? Is it to declare the issues of the day?' the answer was given by W.H. Aldis at the 1926 Convention (MacBeath 1949):

It is the purpose of the Keswick Convention to get away from the hurly-burly of life for just one week, that we might meet with God. To rest and to be with Christ and when we leave we should get involved in the needs of other people. In addition that we might get a clearer view of ourselves. Christ and Him crucified is the centre of the Keswick message. There is no other special message. (p. 68)

Pre-millennialism at Keswick tended to focus on the conversion of individuals rather than toward wider social transformation, which thinking gained more ground. ${ }^{11}$

9.Final address of Andrew Murray in the 1895 Convention.

10.Cf. one of the CIM missionaries, Henry W. Frost, who was introduced in the 1887 Niagara Conference into the pre-millennial teaching. 'It was, rather, the coming of the King and the establishment of His Kingdom. [...] Thus the pre-millennial view of missions, as related to the Lord's return in glory, took the word "duty" out of my missionary vocabulary and put the word "privilege" in its place' (Taylor 1938).

11.For a general consideration of New Testament teaching on this subject, see Grier (1975). 


\section{Opposition}

During the first years of the convention many, especially reformed, Christians were suspicious about Keswick, as they referred to its 'erroneous doctrines'. Throughout the years Keswick stood for the glory of Jesus Christ and his crucifixion for us. Keswick has been established as firm as a rock upon the sacrificial death of Christ and the gift of pardon, which we gain utterly unmerited, through the death of Jesus. Sanctification was a great emphasis of Keswick, but discussion negotiates amongst a Calvinist 'total depravity', a Wesleyan 'eradication' or 'perfection' and a Pentecostal 'baptism by the Holy Spirit'.

In Oxford (1874) evangelical leaders already expressed strong opposition to, what they believed to be, a false doctrine often called 'perfection in man', 'Pearsall-Smithism' or 'sinless perfection'. Convention leaders strongly emphasised that this never had been the teaching, and much prejudice needed to be overcome. Indeed some advocated this doctrine, but the leading principle was that Christ not only was a perfect atonement for sin, but also a keeper of those who trust him up to the measure of their light and knowledge, not of their own need, but of Jesus Christ as their 'life'. Against the persistent allegations by Anglican theologians, Webb-Peploe 'most carefully guarded by an insistence that sin remains in us to the last' (Harford 1907:38-41). Every moment the blood of Christ is needed, every moment of our lives, to cleanse us.

The suggestion that Keswick's teaching of 'Holiness by Faith' was a substitution for 'Justification by Faith' came from Calvinistic proponents. Here Bishop Moule argues (Harford 1907):

It is no substitute for Justification by Faith. Rather it presupposes it; it is itself the sequel truth which justification takes for granted as its complement and crown. And again, it is no contradiction to the inviolable claims of discipline and diligence. (p. 72)

Moule emphasises his point with Marshall's The GospelMystery of Sanctification. ${ }^{12}$ Marshall (1628-1680) was a treasured friend of Richard Baxter, and his teaching, whilst stating largely in Calvinistic terminology, theologically forms a transition to the teachings of the Wesley's in the 18th century. True Christian sanctification presupposes the new birth in Christ and flows from it. 'And this way of sanctification confirms the doctrine of justification by faith, as the apostle informed' ( $\mathrm{Rm} 8: 1)$. For, if we are sanctified and therefore restored to the image of God and live by the Spirit through faith, it is evident that God has taken us into his favour. He pardoned our sins by the same faith and without the law; or else we should not have the fruits and effects of his favour to our eternal salvation ( $\mathrm{Rm}$ 8:2; Marshall 1954:221-222).

Harrington Lees took up the idea from the Methodist tradition that there should be a juncture of full consecration

12. The beauty of Marshall's book is that he makes the mystical union the starting point in the Christian course. He points out how by faith the sinner receives Christ, and His salvation, how justification and sanctification are both given in Christ and and His salvation, how justification and sanctification are both given in Christ and
received only through faith that unites to Him' (quoted by Andrew Murray in Marshall 1954). as well as a subsequent steady progress in the Christian life. He referred to 1 Corinthians 6:11, Romans 6:13, 19; 12:1; 1 Thessalonians 5:23, summarising Moule's Keswick teaching as 'a crisis with a view to a process' (Harford 1907:180).

Critics in the early days complained that the teachers did not give proper prominence and honour to the Holy Spirit, but when this teaching came about the objection altered, faulty teaching about the Spirit was one of the points charged by the opponents. Traditional Calvinists, such as Ryle, were alarmed lest followers of Keswick should delude themselves into supposing that an intense experience could be guarantee of effortless spirituality. They flung at convention-goers the charge of maintaining 'sinless perfection'. Some on the fringe of Keswick indeed taught that sin could be entirely rooted out of believers, but this has never been the official Keswick line. 'Is it true', an enquirer asked at the 1880 Convention, 'that the old nature, with its tendencies to $\sin$, can be wholly eradicated in this life?' The reply from E. Hopkins, the theological guardian of the movement, was a definitive 'no!' (Stevenson 1959:157-162; cit. 436). The Reformation conviction is that believers do not escape from their sinful state until death was sustained. Bishop Ryle (1952) says that holiness is:

the habit of being of one mind with God and a holy man will 'follow after meekness, after temperance and self-denial, after charity and brotherly kindness, a spirit of mercy and benevolence towards others, after purity of heart, after the fear of God, after humility, after faithfulness in all the duties and relations in life, and after spiritual mindedness. (pp. 34-38)

For Ryle holiness was not perfection, but the Christian life is a battle where 'sanctification always is a progressive work [...] The flesh is ever lusting against the spirit and the spirit against the flesh [...] Would you continue holy? Then abide in Christ' (Ryle 1952:39, 50). For a long time Calvinist critique focussed on whether sanctification is a sudden event or a more gradual experience. In the first decade of the 20th century in the Manuel of Keswick teaching of 1906 there is hardly to find a section concerning this issue (cf. Bebbington 1989:169).

An outstanding critic on Keswick theology was Martin LloydJones (1899-1981). Lloyd-Jones represented the Calvinistic branch of Methodism. He saw too much Arminianism in the evangelical movement. In the 1941 Cambridge Easter Conference in Trinity College, Lloyd- Jones spoke on 'The Causes of Present Weakness'. First he opposed the new direction Moody's missions had given to 'evangelism'. For Lloyd-Jones it was a divorce of the Gospel message as presented in the Scriptures from evangelical theology. Methods are more important than the truth (Murray 1990:73). The Keswick 'higher-life' movement also contributed to a reduction of interest in biblical theology and deeper scholarship. Keswick had isolated one doctrine, holiness, and altered it by the false simplicity contained in the slogan, 'Give up, let go and let God' (Murray 1990:73, 74). According to Lloyd-Jones, Keswick theology allows a Christian to have 
an 'un-surrendered life'. For him it was a teaching which rested 'on a seriously defective doctrine of regeneration' (Murray 1990:196). He refers to Bishop Ryle 'who drunk deeply from the wells of the great classical puritan writers' (Ryle 1952:vi).

However, Lloyd-Jones warmly co-operated with the China Inland Mission (CIM) and sometimes had Keswick speakers to his own pulpit at Westminster Chapel. The representative organ of the KC, a weekly evangelical paper, The Life of Faith, of 11 May and 8 June 1974, gave praise to the LloydJones volumes on Romans, despite the criticism of Keswick teaching contained in these volumes. Lloyd-Jones was not outspoken against Keswick. In London he had intense contact with evangelical agencies and missionary societies. He was a close friend of Fred Mitchell, chairman of the $\mathrm{KC}$ and regularly visited the CIM headquarters in London (Murray 1990:96). For him, unity amongst evangelicals was important, but due to his conscientious adherence to Calvinistic principles he twice declined an invitation to speak at Keswick.

In July 1955 James Packer (1955:153-167) gave a very negative overview of 'Keswick and the Reformed Doctrine of Sanctification'. He said that Keswick 'contrasted with the historic Reformed teaching', that is dishonouring God, and the message is 'Pelagian and delusive'. At that time Evangelicalism suddenly found itself under a seeming attack from its own side. Packer's fear was that a gospel, which depends for its success upon man's will and man's response, is not the gospel of the New Testament. He questioned whether it was all according to the teaching of the Puritans, Whitefield and Spurgeon. Serious divisions amongst evangelical Christians at that time hindered the church in fulfilling its main task. Thirty years later Packer had changed his mind and gave a more moderate and even positive approval of the Keswick teaching (Packer 2009:110-137). His alignment with the 2009 Manhattan Declaration, 'A call for Christian conscience', highlights his broader ecumenical motives. The Keswick Council has been very sensitive in the past to recognise the errors in some Keswick teaching and dealt with them. Speakers like Sinclair Ferguson and John Stott would not have associated themselves with the Convention had not Keswick leadership dealt with nonScriptural expositions. The discussion on the Second Advent still continues today. The historic Protestant position is not pre-millenarian. Pre-millennialism holds that Christ's second coming will not follow, but introduce the millennium. The view of the Reformers is that the second coming of Christ is the signal for the final and general judgement.

\section{Keswick today}

The world has changed dramatically since 1875, yet the biblical truths and values that inspired the first meeting in Keswick have not. The conventions, especially in the first week, deal a lot with biblical expositions and do not propagate special Keswick theology.
In 2010 the $\mathrm{KC}^{\prime}$ s theme was very timely: Christ-centred renewal. The chairman, Jonathan Lamb told some 12000 people of varying ages, denominations and cultures (Hull 2010):

It has to be said that we who claim to know Christ often feel that our Christianity can easily become institutionalized or routine, lacking the spiritual vibrancy and devotion that we know is of the essence of living faith. [...] We seek renewal and refreshment as we meet Christ through the power of the Word and Spirit. There are plenty of distractions in our busy lives which can dull our devotion, take the edge off our commitment, and gradually deaden our sensitivity. (pp. 7,8 )

From the first its objective was to meet the needs of those who wanted greater depth in their spiritual lives. That aim has never been changed, but the event has become known for other things, including a determination to see Christians from many denominations working and worshipping together. After nearly 140 remarkable years the KC still seeks to re-emphasise its central convictions and to bring Christians together as being 'All one in Jesus Christ' - the characteristic of its continuing story. Two main positions may be instanced: social and theological. First, amid the worldwide clash of creeds and strife of denominations, which can bring an ordinary Christian into great confusion, it has been found possible, under the banner of the Keswick motto All one in Christ Jesus, for Christians to forget their religious differences in their spiritual union, and to demonstrate to the world that unity in the Spirit is real in its practical application. 'These people have found a way of linking Pentecost with the Sermon on the Mount', as was stated in one of the best known organs of the High Anglican Party a few years ago. No one can deny in the English speaking countries that the $\mathrm{KC}$ has had tremendous impact upon the life of the Christian Church. On all five continents Keswick Conventions are to be found nowadays. The KC has founded no new denomination. It has sought to pour oil upon the heart-stones of all the churches and cold water on none. Its aim has been to send back church members, who have been brought into touch with new possibilities, to impart new vitality to their old churches.

Secondly, Keswick stood not only for the primary evangelical truth of justification by faith as its foundation, but also for a resolute witness to the possibility of a life of holiness, entered and maintained by faith in a living Christ, through the power of the indwelling Holy Spirit. Christians, ministers and churchgoers daily need the awareness that the inner walk of their personal life need to be Christ-like, though they often realise their own failures due to spiritual powerlessness. There is a reduced concern about sin and a widespread temptation to put ambition in place of zeal for God, or even to allow self-advancement as a parallel motive with the expansion of Christ's Kingdom, to look merely at numerical triumphs in attendance at meetings. It is much better to lead a prayerful life and have the souls of unconverted in their hearts. Keswick has been an untold help to many Christians to 'get right with God'. 


\section{Conclusion}

Since 1875 the KC has been expounded the Scriptures. In its theology evangelical, it is conservative and centred upon soteriology, emphasising the redemption of sin and the work of the Holy Spirit in conversion and sanctification. Over the years the centrality of the life of holiness in the believer has been put in the front and after this emphasis on the holiness, God's claim that we should become like him, in faith, which works by love. Right from the beginning, Keswick teaching is controversial as it exposes the very thing that natural man does not want to hear. It is the way in which man is helpless and that only by 'complete surrender' to Christ, he can be brought into a 'redeemed life'. It will always be difficult to give an unbiased view of Keswick teaching. Due to the undenominational leadership and the thousands of the visitors to the yearly conventions from various churches, everyone with the desire to listen to the Bible expositions, a vision on the same tenor on various biblical topics is a desideratum. All intend and feel unity and sympathy with Christians from all over the country and abroad. In Keswick it is unity in the basic Christian doctrines of salvation and the truth of the Bible is not negotiable. However, in interpretation some go different ways. I agree with Wigram (2007:64) that Keswick created a common spirituality of Christian experience that revitalised many congregations and may lead to missionary service.

Keswick leaders did not want preachers at the conventions to ride their own theological hobby-horses. Christian holiness is no cloistered virtue, but a call to live in the world as men and women who are separated to the world and yet have a world-transforming message and mission. It is nothing less than a call to follow our Saviour and heed the continuing obligation of the great commission. The KC channelled the insights of many evangelicals of the late 19th and 20th century: to deal with and to harmonise their spirituality with the new challenges of their time. Keswick will bring transformation to individual and church communities alike. The KC, which commenced in the 19th century, is showing today that it remains alive and well. Sustaining its core convictions, it is applying them freshly to the challenges faced by today's church. The teaching nowadays at KC has moved away from 'the higher life' emphasis and now represents a broader section of conservative evangelicalism. The fact that the event is expanding, recapturing new generations of believers and transforming individuals and churches, is testimony that it continues to emphasise something significant. Keswick wants to listen to Christ and does not want to be pre-occupied with lesser things. Keswick's evangelical spirituality moulds a message in which salvation, in all its fullness, requires service as its outcome - a teaching that a definite step must be taken, a simple and momentary trust exercised, and that God is able to keep and to enable for whatever he calls us to.

\section{Acknowledgements Competing interests}

The author declares that he has no financial or personal relationship(s) that may have inappropriately influenced him in writing this article.

\section{References}

Barabas, St., 1952, So Great Salvation: The history and the message of the Keswick Convention, Wipf \& Stock, Eugene.

Bebbington, D.W., 1989, Evangelicalism in Modern Britain: A history from the 1730 s to the 1980s, Routledge, Abingdon.

Boardman, W., 1859, The Higher Christian Life, Henry Hoyt, Boston.

Chadwick, O., 1966, The Victorian Church, vol. 1, Adam \& Charles Black, London.

Chadwick, O., 1971, The Victorian Church, vol. 2, Adam \& Charles Black, London.

Chambers, O., 2000, The Complete Works, Discovery House Publishers, Grand Rapids.

Cummings, J.E., 1875, 'Leaders of the Keswick Convention 2', viewed 12 January 2014, from patonix.hubpages.com

Douglas, W.M., 1981, Andrew Murray and His Message, Baker Book House, Grand Rapids.

Gibson, W., [1860] 1989, That Year of Grace, Ambassador, Belfast.

Gordon, J.M., 1991, Evangelical Spirituality, Society for Promoting Christian Knowledge, London.

Grier, W.J., 1975, The Momentous Event: A discussion of Scripture teaching on the Second Advent, The Banner of Truth Trust, Edinburgh.

Harford, C.F., 1907, The Keswick Convention: Its Message, Its Method and Its Men, Marshall Brothers, London.

Hull, A. (ed.), 2010, Christ-Centered Renewal: How Christ Changes All Of Life, Authentic Crownhill, Milton Keynes.

MacBeath, W.H., 1949, W.H. Aldis, Marshall, Morgan \& Scott, London/ Edinburgh.

Marshall, W., [1692] 1954, The Gospel-Mystery of Sanctification, Zondervan, Michigan.

Murray, I.H., 1990, David Martin Lloyd-Jones: The Fight of Faith 1939-1981, vol. 2, The Banner of Truth Trust, Edinburgh.

Murray, I.H., 1996, Revival \& Revivalism, The Banner of Truth Trust, Edinburgh.

Murray, I.H., 2013, 'Evangelical Holiness and Spirituality: A lecture at the Keswick Convention, July 28, 2010', in I.H. Murray, Evangelical Holiness and other addresses, pp. 1-39, The Banner of Truth Trust, Edinburgh.

Packer, J.I., 1955, 'Keswick and the Reformed Doctrine of Sanctification', Evangelical Quarterly 27, 153-167, July-September.

Packer, J.I., 2009, Keep in Step with the Spirit: Finding fullness in our walk with God, InterVarsity Press, Nottingham.

Pierson, A.T., 1903, The Keswick Movement in Precept and Practice, Funk \& Wagnalls Co., New York/London.

Pollock, J.C., 1964, The Keswick Story: The authorized history of the Keswick Convention, Hodder \& Stoughton, London.

Price, C. \& Randall, I., 2000, Transforming Keswick: The Keswick Convention Past, Present \& Future, OM Publishing, Carlisle.

Rowlandson, M.L., 1997, Life at the Keswick Convention, OM Publishing, Carlisle.

Ryle, J.C., [1877] 1952, Holiness: Its Nature, Hindrances, Difficulties, and Roots, Fleming H. Revell Co., Old Tappan, NJ.

Sloan, W.B., 1935, These Sixty Years: The Story of the Keswick Convention, Pickering \& Inglis, London/Edingburgh.

Smith, R.P. \& Smith, H.W., 1873, The Christian's Secret of a Happy Life, J.B. Lippincott $\&$ Co., Philadelphia.

Stevenson, H.F. (ed.), 1959, Keswick's Authentic Voice: Addresses delivered at the Keswick Convention 1875-1957, Zondervan, Grand Rapids.

Stevenson, H.F. (ed.), 1963, The Ministry of Keswick: Bible readings delivered at the Keswick Convention, 1st ser., 1892-1919, Marshall, Morgan \& Scott, London.

Stott, J., 2008, John Stott at Keswick: A Lifetime of Preaching, Authentic, Colorado Springs.

Taylor, H., 1930, Guinness of Honan, CIM, London/ Shanghai.

Taylor, H., 1938, By Faith, Henry W. Frost, CIM, Philadelphia/ London.

The Keswick Week, 1930, 1947, 1955, 1959, 1962, Official publication of the KC with the addresses of the yearly convention.

TKW see The Keswick Week

Webb-Peploe, H.W., 1910, That Beautiful Name: Bible readings given at the Keswick Convention, July, 1910, Marshall Brothers, Ltd, London.

Wigram, C.E.M., 2007, The Bible and Mission in Faith Perspective: J. Hudson Taylor and the Early China Inland Mission, Boekencentrum, Zoetermeer. 